\author{
Јован М. ЧУДОМИРОВИЋ* \\ Филолошки факултет \\ Универзитета у Београду
}

\title{
ПОЛИФУНКЦИОНАЛНОСТ КЛАУЗА СА ВЕЗНИКОМ ЧИМ
}

\begin{abstract}
У раду се из когнитивнолингвистичке перспективе анализирају употребе зависних клауза са везником чим у различитим доменима - домену садржаја, епистемичком домену и домену говорних чинова. Та анализа даје два битна резултата: да ове клаузе нису нужно временске, већ да се употребљавају и у епистемичком домену да изразе премису из које се изводи неки закључак, као и да ни у домену садржаја готово никад не обележавају чисто временски однос, већ увек имплицирају и неку компоненту условљености или каузалности у односу између садржаја зависне клаузе и више клаузе. У закључним разматрањима издвајамо три битна фактора одговорна за овакву полифункционалност чим-клауза: метонимијску везу између сукцесивности и каузалности; специфичност временског односа који обележава везник чим; и чврсту утемељеност метафоричке концептуализације закључивања као каузалности.
\end{abstract}

Кључне речи: везник чим, временске клаузе, узрочне клаузе, имедијатност, условљеност, каузалност, теорија домена, метафора, метонимија.

\section{1. Увод}

Клаузе с везником чим уобичајено се сматрају временским и тако се класификују у граматикама (Стевановић 1969: 876-877; Мразовић 2009: 593-594). Међутим, ове клаузе имају и једну употребу у којој би се тешко могле сматрати временским, већ би прикладније било рећи да се њима износи премиса у закључивању (уп. Чим он то каже, сигурно ти не верује); о овој употреби у литератури се говори ређе (Стевановић (1969: 893-894) овакве клаузе сматра узрочнима; један пример помиње и П. Мразовић (2009: 599) и такође такве клаузе, као и Стевановић, назива узрочним). Циљ овог рада је да расветли овакву полифункционалност из когнитивнолингвистичке перспективе, ослањајући се на концепцију домена̂ (Свитсер 1990).

*j.cudomirovic@gmail.com 
Према овој концепцији, различите функционалне речи и конструкције које оне образују могу проширивати своју употребу из основног домена, тзв. домена садржаја, у друге домене. Тако следећи примери илуструју употребу везника јер и узрочне клаузе у различитим доменима:

(1) Вода се заледила, јер је веома хладно.

(2) Мора бити да је веома хладно, јер се вода заледила.

(3) Можеш ли да ме позовеш касније, јер сад имам много посла?

У првом примеру садржајем узрочне клаузе износи се реални узрок залеђивања воде; у том случају узрочно-последични однос постоји између садржаја узрочне клаузе и садржаја (остатка) више клаузе, па се говори о каузалности у домену садржаја (Свитсер 1990). У другом примеру пак узрочном клаузом не износи се реални узрок (то што се вода заледила није узрок томе што је хладно), него премиса од које се полази у закључивању. Овде се, дакле, ментални процес закључивања метафорички концептуализује као каузалност у епистемичком домену (Свитсер 1990). Најзад, у трећем примеру реч није ни о домену садржаја ни о епистемичком домену, већ о томе да се узрочном клаузом исказује разлог, образложење за говорни чин молбе изречен остатком више клаузе. Овде је, дакле, садржај клаузе усмерен не на садржај остатка више клаузе, него на његову илокуциону снагу, па са оваква употреба назива употребом у домену говорних чинова. Овакав приступ полифункционалности везника и конструкција које они образују већ се показао као погодан теоријски оквир у истраживањима на материјалу напоредних везника одн. напоредних конструкција, као и појединих типова зависних клауза (уп. Чудомировић 2015a; Чудомировић 2016; Чудомировић 2019), па и овде полазимо од њега.

Корпус за ово истраживање чини 238 примера клауза са везником чим ексцерпираних из Електронског корпуса савременог српског језика (ЕКСЈ). ${ }^{1}$ Од тог броја, до 180 примера дошли смо бирајући опцију случајног избора ниски које садрже везник чим. Пошто се испоставило да је употреба у домену садржаја толико фреквентна да се у 180 случајно одабраних примера налазе само два примера употребе у епистемичком домену (док су сви остали илустровали домен садржаја), до преосталих примера дошли смо сужавајући упит на ниске које почињу везником чим а у наредних десет речи садрже неки од маркера закључивања (о њима више у одељку 2.2) или пак облике императива.

У наставку овог рада изложићемо резултате анализе спроведене на овако добијеном корпусу, а затим изнети закључке на које та анализа упућује.

\footnotetext{
${ }^{1}$ Корпус се развија на Математичком факултету Универзитета у Београду, а налази се на адреси http://korpus.matf.bg.ac.rs.
} 


\section{2. Анализа}

\section{1. Домен садржаја}

\subsection{1. Између имедијатности и условљености}

За клаузе са везником чим обично се истиче да означавају постериорност ситуације у вишој клаузи, и то непосредну постериорност, тзв. имедијатност (Антонић 2001; Антонић 2018). Ређе се, међутим, истиче да такав временски додир две ситуације готово увек подразумева везу која је јача од пуке сукцесивности - неку чвршћу, унутрашњу повезаност, тј. условљеност између двеју ситуација. Док временске клаузе с неким другим субординаторима могу послужити да временски локализују ситуацију више клаузе а да се притом не имплицира нека међусобна условљеност тих ситуација (уп. нпр. Кад сам отворио прозор, напољу је падала киша, Док смо били на одмору, реновиран је парк испред наше зграде и сл.), клаузе са чим такву условљеност имплицирају готово увек. Кад је реч о типу те условљености, у нашем материјалу издвајају се два типична случаја.

У првом случају, клауза са везником чим означава ситуацију која представља предуслов за реализацију ситуације у вишој клаузи одн. омогућава да се ситуација у вишој клаузи оствари:

(4) Према Топчагићевим речима пројектовање је завршено, Брисел је прихватио 24 пројекта, ,припрема се финансијски споразум за њихову реализацију и чим буде верификован, односно потписан следи расписивање тендера". (Политика, 16. ХІ 2009)

(5) Он је такође најавио да ће у министарствима правосуђа две државе ускоро бити доступни спискови Срба оптужених за ратне злочине у Хрватској. Шимоновић је додао да ће то бити „врло брзо” чим буду решени технички проблеми. (Политика, 18. V 2010)

(6) Према ранијем плану, Ахтисари је требало да свој предлог упути Савету безбедности чим га напише - као документ УН. (Политика, 7. II 2007)

(7) Послушно сам климнуо главом и рекао да ћу ускоро закуцати на њена врата, чим оставим скије, обујем патике и оперем руке. (Р. Кузмановић, Голф)

(8) И много година раније (им је стасао) $)$ не мирећи се са оптужбом да су му родитељи „народни непријатељи”, који су, ни криви ни дужни, бачени у неку раку сремске равнице, Слободан је куцао на разна врата. (Политика, 19. VI 2007)

(9) Предузетници и предузећа би са пословањем могли да крену одмах, чим попуне неопходна документа за регистрацију, која би потом могла бити одбијена смо у случају неправилно датих података. (Економист магазин)

(10) Сутра, још у црну зору, чим би се истрезнио, одмах се дизао и одлазио натраг, у хан, село. (Б. Станковић, Нечиста крв) 
(11) Од њега сазнајемо да „у Кенији живе од туризма, канге, резбарија у дрвету, чаја и пољопривреде". Одлична идеја. Решио сам и ја да живим од канге, чим будем сазнао шта је то канга ! (НИН, 24. I 2002)

У примеру (4) потписивање финансијског споразума је корак без ког не може уследити расписивање тендера, што је ситуација означена вишом клаузом; у примеру (6) предлог се не може упутити док није написан итд. У свим примерима, дакле, ситуација означена чим-клаузом не претходи ситуацији из више клаузе само по времену реализације, него и по томе што представља нужан услов за остварење те ситуације. Предикат чим-клаузе у оваквим случајевима најчешће је свршени глагол у презенту или футуру II, мада има и другачијих случајева (уп. перфекат у примеру (8) и потенцијал који означава понављану радњу у примеру (10)).

Условљеност између ситуације коју означава чим-клауза и оне коју означава виша клауза налазимо и у следећој групи примера, али је карактер те условљености нешто другачији:

(12) Е, видите, чим је одјекнуло ваше име, мој отац је окренуо главу. Ја сам чврсто веровала (видите колико сам била луда!) да ће сви присутни бити погођени тим именом као громом, те ми се учинило да је мој отац уздрхтао, па чак и господин Данглар (али за овога верујем да ми се само тако причинило). (А. Дима, Гроф Монте Кристо)

(13) Чим је угледао натпоручника Лукаша, Швејк поче да му значајно намигује. (Ј. Хашек, Доживљаји доброг војника Швејка)

(14) То је потврдио и министар безбедности БиХ Тарик Садовић, који је рекао да ће Главаш, после саслушања у сарајевском тужилаштву, бити пуштен на слободу, али неће смети да напушта територију те државе, jep ће, због потернице, бити ухапшен чим пређе границу. (PTC, 13. V 2009)

(15) Сутрадан сам са нестрпљењем очекивао поноћ. Чим је избила, сео сам крај прозора. (Ј. Потоцки, Рукопис нађен у Сарагоси)

(16) Суд је везан за своју пресуду чим је објављена, а ако пресуда није објављена, чим је отправљена. (Закон о парничном поступку)

(17) Чим се дознало да све предвиђено неће бити реализовано, кренула су и у самом медицинском центру питања као што су, рецимо: зашто су паре трошене на претварање осам болничких соба у апартмане и за уређење неких лекарских канцеларија? (Политика, 20. IV 2007)

(18) Али ипак је шума и надаље остала дивља и опасна, све док једног лепог дана неки путник, који беше продро до у само њено срце, случајно не откри да брдо скрива у својој утроби руде. Чим се ово рашчу, поврвеше рудари и радници у шуму да ваде то благо. (С. Лагерлеф, Чудновати доживљаји Нилса Холгерсона) 
(19) Према другим причама Атех уопште није била лепа, али је своје лице пред огледалом увежбала да узме такав израз и да тако распореди црте да стекне леп облик. Та увежбана лепота изискивала је од ње огроман физички напор и чим би принцеза остала сама и опустила се, њена лепота би се расула као њена со. (М. Павић, Хазарски речник)

(20) По правилу, Црква је оптужене свештенике премештала у друге диоцезе чим би против њих била покренута истрага. (Политика, 10. XI 2007)

У наведеним примерима ситуација из чим-клаузе узрокује ситуацију из више клаузе. То јест, оствареност ситуације из чим-клаузе у овим случајевима довољна је да произведе ситуацију из више клаузе: то што је чуо одређено име, неизбежно наводи оца да окрене главу (12), Швејку није потребан никакав други подстицај да почне да намигује Лукашу од тога што га је угледао (13), након што уђе у земљу, особа с потернице неизбежно ће бити ухваћена итд. (14). (У неким од наведених примера овај довољан услов је уједно и нужан, али то није увек случај.) Пошто подразумевају узрочно-последичну везу између две ситуације, у примерима из ове групе могуће је чим заменити неким од узрочних субординатора, што није случај с примерима (4)-(11). ${ }^{2}$

Примери конструкција са чим-клаузом у којима условљеност између две ситуације није очигледна релативно су ретке. У нашем материјалу налазимо свега седам таквих примера, при чему се, како ћемо показати, и у некима од њих може препознати условљеност потоње ситуације претходном.

(21) Говорена реч, велите, умире често чим се роди, а живи у најбољем случају док још има кога да је се сећа. Писана реч, напротив, дужега је века, а има их које вечито живе. (М. Миланковић, Кроз васиону и векове)

(22) „Медени месец” похвала, честитки и бодрења после објаве да је Караџић ухапшен завршен је малтене чим је почео. (Политика, 1. VIII 2008)

(23) Смедеревци су опасно припретили Црвеној звезди чим је утакмица почела. (Политика, 14. ХІ 2000)

(24) Црне Анине очи, сјајне од суза и осмеха, видео је Бунчук чим је први пут отворио очи. (М. Шолохов, Тихи Дон)

(25) Један ратник трчао је до Атине 42 км да би донео вест о победи. Чим је саопштио вест, пао је од умора и умро. (И. Божић, Историја за V разред основне школе)

(26) - Алонсо, - рекла је - честити Алонсо, победио си. Сенке мојих отаца су умирене. Срце које није требало да припада ни једном смртнику постало је твоје и то ти је награда за жртве које не пре-

\footnotetext{
${ }^{2}$ Треба имати на уму да у примерима као што су они из групе (1)-(8) то често није могуће зато што је у чим-клаузи употребљен свршени презент/футур II употребљени да означе још неостварену радњу. Међутим, парафраза узрочном клаузом не чини се адекватном ни у примерима (5) и (8), где поменуте препреке нема.
} 
стајеш да приносиш за добро мојих несрећних земљака. Чим је изговорила те речи, Тласкала ми је пала у наручје без свести и скоро без даха. (Ј. Потоцки, Рукопис нађен у Сарагоси)

(27) Мунћанова је данас трчала много слабије и са 4:15,18 била тек 12. у својој групи, а 34. укупно. - Не знам шта се догодило. Јутрос сам била потпуно спремна и орна за трку, али чим смо кренуле знала сам да нешто није у реду. (Политика, 19. VIII 2009)

У примерима (21)-(24), као и у примерима (4)-(11), ситуација у зависној клаузи заправо је нужан услов, тј. предуслов који се мора испунити да би ситуација у вишој клаузи уопште била могућа: ништа не може умрети ако претходно није рођено (21), нити се може завршити ако претходно није почело ((22), (23)) итд. Разлика између примера (21)-(24) и примера (4)-(11) само је у томе што се у примерима (21)-(24) не очекује да исход који се саопштава остатком више клаузе наступи тако брзо или се не очекује уопште, док у примерима (4)-(11) то није случај.

У примерима (25) и (26) условљеност између две ситуације теже је доказати: ни ратник ни Тласкала свакако нису пали зато што су изговорили неке речи, али би се могло претпоставити да у оба случаја изговарање речи представља некакав циљ који већ исцрпљеном говорнику даје снаге да издржи онолико колико је потребно да буде испуњен. Стога ни овде однос између ситуације исказане чим-клаузом и оне исказане остатком више клаузе није искључиво временски, мада је условљеност ситуације из више клаузе оном из зависне овде више имплицитна него у претходним примерима.

Најзад, у примеру (27) тешко је тврдити да је кретање било не само узрок него ни предуслов за то да говорница схвати да нешто није у реду, иако је и о томе могуће спекулисати (могуће је, на пример, да уласком у трку тркач стиче бољу представу о свом тренутном стању, могућностима итд., па му је тада лакше да интуитивно препозна проблем). Дакле, тек би се у овом случају можда могло говорити о чистој имедијатности.

\subsection{2. Аспекатска конфигурација конструкција са чим-клаузом у домену садржаја и позиција чим-клаузе у домену садржаја}

Из досад наведених примера већ је очигледно, а то је потврђено и у литератури (Антонић 2018: 320-321), да су типичне аспекатске конфигурације оваквих конструкција она са свршеним глаголом и у чим-клаузи и у вишој клаузи (што можемо означити као с̌IMPF-PF), или пак са свршеним глаголом у чим-клаузи, а несвршеним у вишој (што можемо означити као с̌ІмРF-IPF).

У нашем материјалу, од 187 примера у домену садржаја, у 123 је аспекатска конфигурација с̌IмPF-PF (свршени глагол и у чим-клаузи и у вишој клаузи, рачунајући овде и сложене предикате са свршеним фазним глаголом), a у 32 примера с̌ıмPF-IPF (свршени глагол у чим-клаузи, а несвршени у вишој клаузи). Остатак отпада на случајеве у којима је предикат једне од клауза копулативни, егзистенцијални или сложени с модалним глаголом, као и на 
најређи случај - онај у ком је предикат чим-клаузе несвршени глагол. У нашем материјалу налазимо само два таква примера:

(28) Вукашин Ђорђевић из Иванче добио је касету Радета Лацковића, а омиљена песма му је „Кучка”. ,Чим будем правио свадбу неком од деце, позваћу Радета на свадбу [...]”. (Свет, бр. 220)

(29) Променио сам неколико послова откад сам се вратио, и свуда срећем људе који преузимају ритам живота са Запада, али веома селективно. Чим им нешто смета, одмах крену о западњачкој етици. (Политика, 25. XII 2006)

Што се тиче позиције чим-клаузе у домену садржаја, у нашем материјалу су и иницијални и финални положај релативно једнако чести: примера са чим-клаузом у иницијалном положају има 93, у финалном 82, а 12 је примера у којима је чим-клауза у медијалном положају. У одељку 2.2.2 видећемо да је овај однос у епистемичком домену битно другачији.

\section{2. Епистемички домен}

\subsection{1. Чим-клаузе и однос закључности}

Како је већ речено у уводном одељку, примери употребе чим-клауза у епистемичком домену далеко су ређи од оних у домену садржаја и случајним избором се добија врло мало таквих примера. Ипак, циљаним претраживањем могуће је доћи до већег броја примера чим-клауза у епистемичком домену (у нашем материјалу их је укупно 48), а овде наводимо неке од њих.

(30) Сведоци смо, сваког дана, убрзане ерозије морала. У нашем цирозираном друштву и кородираној стварности млади се жртвују да би нечашће старијих опстало. За њихов положај они слабо маре, чим их користе за циљеве старе, а то је да остану на власти. Млади су гурнути у ватру. Уместо да с нестрпљењем очекујемо њихове животне успехе, ми смо их послали у њима необјашњене пределе суровости и немилице живота. (Политика, 26. II 2008)

(31) И то је слободна Србија! Чим не мислиш како мисли пандур, завереник си против краља и главу ти скидају. (Д. Ћосић, Корени)

(32) Тако је било и после питања да ли претходна изјава значи да су тренери криви. - Чим нешто није спроведено у дело, неко мора да буде крив - рекао је Ценић. (Политика, 9. VIII 2000)

(33) Знам критичара који не зна ни зашто је критичар. Чим је критичар, за њим потреба мора да постоји. (Политика, 11. III 2006)

(34) - Има ли што ? - упита. - Још ништа. Чим багрем овако мирише, биће кише. - Па шта Роза каже? (Д. Ћосић, Корени)

(35) Значи, није могло бити ни арбитраже на основу непостојећег уговора. За то је потребна сагласност две стране, а ње није било, цим нема уговора. (Политика, 20. V 2010) 
(36) У осталим случајевима трговци су обезбеђени, јер чим нема датума на папиру, онда таква трговина није у супротности са законом, а чек није чек док се не датира. (Политика, 24. XII 2005)

За разлику од примера употребе у домену садржаја, овде чим-клауза више не служи да временски лоцира ситуацију више клаузе као непосредно постериорну у односу на ситуацију зависне. Тако се у примеру (30) време више и време зависне клаузе заправо поклапају. Притом, чим-клаузом не обележава се временски однос симултаности, него то да садржај зависне клаузе служи као основ на ком се износи закључак који доноси остатак више клаузе. Слично томе, не мислиш као пандур служи као основ за закључак против краља си (31), нешто није спроведено у дело као основ за закључак неко мора да буде крив итд. А да је у питању употреба у епистемичком домену види се и по томе што је у свим случајевима конструкцију са чим-клаузом могуће парафразирати условном конструкцијом са изразом значи да у аподози: Aко ux користе за старе ициьеве, (онда) то значи да слабо маре за њихов положај (30), Ако не мислиш како мисли пандур, (онда) то значи да си завереник против краља (31), Ако нешто није спроведено у дело, (онда) то значи да неко мора да буде крив (32) и сл.

У наведеним примерима закључни карактер односа између зависне клаузе и више клаузе није експлицитно обележен, али то може бити случај, а као конкретизатори закључности најчешће се појављују маркери вероватно, значи (да), сигурно, засигурно, очигледно, мора да и сл.:

(37) И изрека каже да прави живот почиње тек после четрдесете. Почиње, како да не: ујутру се будим са боловима, што је одличан знак

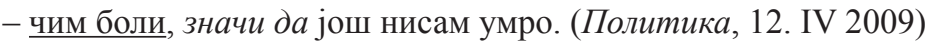

(38) Ако надлежни из Фонда ПИО пронађу пријаву на осигурање која није уговор о делу, позивају их на контролни преглед. Чим нешто раде, значи да немају потпуни губитак радне способности на основу којег су стекли инвалидску пензију, објашњавају у фонду. (Политика, 17. Х 2010)

(39) „[...] Чим смо се почели рађати и крштавати значи да ће нас бити овде и да има наде и живота за Србе у Мостару", истиче свештеник Круљ. (Политика, 18. IV 2009)

(40) Приспело се до оног „ах, да” - а не беше ли Фратков и шеф економског одељења амбасаде СССР у Њу Делхију (1973)? Беше. Па, значи...? Значи. Чим га председник Путин познаје лично, вероватно је да „значи”. (Политика, 18. ХІ 2007)

(41) Чим постоји интересовање за моје концерте значи да људима недостаје квалитетна поп музика. (Политика, 25. Х 2006)

(42) Војислав Маринковић је опет био најгласнији и најсистематичнији. Чим тражи овакво овлашћење - приметио је - влада очигледно нема намеру да, као што је то по уставу дужна, склопљени уговор поднесе скупштини на одобрење. (О. Поповић Обрадовић, Парламентаризам у Србији 1903-1914) 
(43) Чим се, међутим, нешто потискује, чим нема довољно слободе или [чим] друштво нема довољно слуха за научну мисао, сигурно се креће ка новим грешкама и једностраностима - каже овај историчар. (Политика, 7. VII 2010)

(44) Ви засигурно знате да долази замена за мог мужа чим сте тако дрски, и та замена мора да је неки ваш заштитник. (М. Новаковић, Страх и његов слуга)

(45) Чим човек говори о Богу и ђаволу мора да је луд. (И. Андрић, Травничка хроника)

(46) Поведе ме на плочник, добро је, мислим, чим ме будалом зове, мора да ме позно, обазире се око себе и уз зид ме прибија. (Б. Пекић, Одбрана и последњи дани)

(47) Чим је толико окретан, мора да је мувара, то је овде једно те исто. (Пешчаник ФМ, књ. 1)

Семантика конкретизатора који се појављују у вишој клаузи у оваквим случајевима говори нешто и о карактеру закључивања које се изражава оваквим конструкцијама са чим-клаузама. Међу конкретизаторима у примерима (37)-(47) налазимо два типа јединица: једно су маркери (епистемичке) модалности вероватно, сигурно, засигурно, а друго су маркери (инференцијалне) евиденцијалности очигледно и мора да. Иако између ова два типа маркера постоје битне разлике (маркери епистемичке модалности изражавају само степен уверености, а маркери инференцијалне евиденцијалности подразумевају и да постоји конкретан основ/доказ на ком се уверење заснива; више о овоме в. у Вимер и Врдољак 2011a; 2011б; Чудомировић 2013; Чудомировић 2015б), повезује их једна важна заједничка особина - и једни и други подразумевају висок степен сигурности говорника у оно што тврди.

Да је то тако, види се и по томе што у ЕКСЈ нисмо нашли одговарајуће примере с маркерима закључивања који подразумевају умерену увереност, као што су можда или може бити. Штавише, чини се да би такви примери били на граници прихватљивости:

(48) 'Чим човек говори о Богу и ђаволу, можда је луд.

(49) 'Чим је толико окретан, можда је мувара.

Другим речима, може се тврдити да употреба чим-клаузе у епистемичком домену искључује закључивање с умереном сигурношћу, већ имплицира снажну увереност. Објашњење за то пак треба тражити у основној, типичној употреби чим-клаузе, тј. у карактеру временског односа који оне обележавају. Тај однос метонимијски је близак односу каузалности, а каузалност служи као изворни домен за метафоричку концептуализацију закључивања као узроковања. То је механизам којим, између осталих, и везник чим (па и клаузе с овим везником) проширује своју функцију из подручја временских односа у подручје каузалности, а онда у епистемички домен, тј. закључивања. При свему томе, међутим, његова особеност у подручју темпоралне семантике - обележавање имедијатности - у епистемичком домену се транс- 
формише у особеност другог типа - обележавање снажне уверености. Дакле, као што у домену садржаја блиска временска веза готово нужно имплицира и неку условно-узрочну везу, тако у епистемичком домену та блискост подразумева готово нужно логичко слеђење од премисе ка закључку, па отуд и овакве конструкције нужно обележавају високу увереност говорника у оно што тврди.

\subsection{2. Аспекатска конфигурација конструкција са \\ иим-клаузом у епистемичком домену и позиција чим-клаузе у епистемичком домену}

На почетку овог одељка видели смо да је чим-клаузе у епистемичком домену могуће употребити и без експлицитних маркера закључивања. Међутим, и тамо где нема маркера закључивања, на закључност конструкције готово увек упућује аспекатска конфигурација конструкције са чим-клаузом, а пре свега вид глагола који је предикат чим-клаузе.

Наиме, видели смо да је у домену садржаја далеко најчешћа аспекатска конфигурација с̌ıмРF-PF, док је примера с несвршеним пунозначним, копулативним или егзистенцијалним глаголом у чим-клаузи далеко мање. У епистемичком домену ствари стоје сасвим другачије: од 48 примера чим-клауза у епистемичком домену, у 35 предикат је несвршени пунозначни глагол, копулативни глагол или егзистенцијални глагол, при чему је такав најчешће и предикат више клаузе, док свршени глагол у предикату више клаузе налазимо у само пет случајева.

У епистемичком домену примера са свршеним глаголом у чим-клаузи има, али знатно мање - у нашем материјалу је 10 таквих примера (овде наводимо по један пример са копулативним и несвршеним пунозначним глаголом у вишој клаузи, а пример с егзистенцијалним глаголом у вишој клаузи већ смо раније навели, в. пример (39)):

(50) Навикла сам се на то. Чим сам нешто обукла, значи да се у томе угодно осећам. (Свет, бр. 213)

(51) И радници који изводе грађевинске радове у манастиру видели су оца Симеона како потпуно нормално хода без храмања након што је удаљен из манастира. ,Чим је стављен гипс значи да је повреда озбиљна [...]" (Политика, 25. VIII 2008)

Конструкције са чим-клаузом у епистемичком домену показују још једну структурну специфичност, а она се тиче позиције чим-клаузе. За разлику од домена садржаја, где се чим-клауза релативно подједнако појављује и у иницијалном и у финалном положају, у епистемичком домену упадљиво је префериран иницијални положај, који налазимо у 45 од 48 примера у епистемичком домену, са само три примера у којима је чим-клауза у финалном положају (примера са чим-клаузом у медијалном положају у епистемичком домену у нашем материјалу нема). 
Преферираност иницијалног положаја у епистемичком домену вероватно има везе с чињеницом да у закључивању премиса природно претходи закључку, па се та преференција одражава и у распореду клауза. Питање је, међутим, да ли ово важи и у другим случајевима у којима се зависном клаузом износи премиса, а остатком више закључак, пре свега у узрочним клаузама употребљеним у епистемичком домену (о њима в. Чудомировић 2016), што остаје тема за неко будуће истраживање.

\section{3. Домен говорних чинова}

За разлику од домена садржаја и епистемичког домена, чим-клаузе се у домену говорних чинова употребљавају крајње маргинално. У нашем материјалу налазимо само три примера употребе у домену говорних чинова, при чему се, како ћемо показати, они могу интерпретирати и у епистемичком домену.

(52) Ове савете примените само у случају почетних пожара малих размера, поручује Станковић. - Чим осетите дим, знајте да има и ватре, и одмах реагујте. (Политика, 9. V 2010)

(53) Помисао да постоји икаква алтернатива уласку у Европу дефинисану Бриселом је деликт мишљења, али чим вам неко каже да алтернативе нема, знајте да је сигурно има. (Пешчаник ФМ, књ. 1)

(54) Не једном сам чуо, током боравка на једној клиници, да је болесник другом болеснику рекао: „цим су тебе сместили у 'шестицу' спремај се за светог Петра!” (В. Адамовић, Психосоматска медицина и консултативна психијатрија)

Примери (52) и (53) формално би се могли анализирати као примери у домену говорних чинова, под претпоставком да независна клауза у њима има илокуциону снагу директива, нпр. савета. Но чини се да је овакву употребу уверљивије анализирати као специфичан пример употребе у епистемичком домену, при чему би императив глагола знати у другом лицу служио као експресивни маркер уверености.

Слично важи и за пример (54), с тим што је ту, чини се, мање очигледно која би од две интерпретације била уверљивија - ако се илокуциона снага независне клаузе интерпретира као савет, у питању је употреба у домену говорних чинова, а ако се интерпретира као категоричка тврдња (Спремај се за светог Петра! = 'Сигуран сам да су ти дани одбројани'), у питању је епистемички домен. 


\section{4. Закључци}

Анализа коју смо спровели упућује на неколико основних закључака. Најпре, иако је однос између ситуације у зависној и оне у вишој клаузи који изражавају зависне клаузе с везником чим примарно временски, он готово никад није искључиво временски, већ скоро увек има и условну/узрочну компоненту. Стога се и за клаузе с везником чим у домену садржаја може рећи да нису чисто временске, него да унутар категорије временских клауза заузимају место најближе узрочним клаузама и, уопште, читавој групи клауза чија значења припадају „категоријалном комплексу условљености” (Војводић 2018: 433-434).

Овакав статус временских клауза с везником чим проистиче из природе временског односа који изражавају: у нашем искуству, ситуације које следе непосредно једна за другом готово никад нису случајно временски блиске, већ прва на неки начин условљава или узрокује другу.

А семантичка блискост имедијатности и каузалности чини чим-клаузе посебно погодним за проширивање функције из домена садржаја у епистемички домен, јер се закључивање типично концептуализује као каузалност у логичкој/менталној сфери. У том погледу ове клаузе су најближе узрочним клаузама, али не било ком типу узрочних клауза, већ пре свега онима које су специјализоване за изражавање каузалности у епистемичком домену, попут оних чија су обележја субординатори будући да и (c) обзиром (на то) да (в. Чудомировић 2016). Притом, основно значење имедијатности сужава семантички простор који чим-клаузе могу покрити у епистемичком домену - оне не могу изразити премису у било ком закључивању, већ само тамо где је говорник веома уверен у оно што тврди.

\section{ЛИТЕРАТУРА}

Антонић 2001: Ivana Antonić, Vremenska rečenica, Sremski Karlovci - Novi Sad: Izdavačka knjižarnica Zorana Stojanovića.

Антонић 2018: Ивана Антонић, „Реченице с временском клаузом”, у: П. Пипер (ред.), Синтакса сложене реченице у савременом српском језику, Београд - Нови Сад: Институт за српски језик -Матица српска, 289-364.

Вимер и Врдољак 2011a: Björn Wiemer, Ivana Vrdoljak, „Evidenzielle Partikeln vs. Satzadverbien im Serbisch-Kroatischen und Slovenischen. Teil I. Ein Forschungsbericht", Die Welt der Slawen, LVI/1, 100-130.

Вимер и Врдољак 2011б: „Evidenzielle Partikeln vs. Satzadverbien im Serbisch-Kroatischen und Slovenischen. Teil II - Auswertung eines Forschungsberichts", Die Welt der Slawen, LVI/2, 360-383.

Војводић 2018: Дојчил Војводић, „Реченице са клаузама категоријалног комплекса условљености: узрочним, посљедичним, циљним, погодбеним, допусним", у: П. Пипер (ред.), Синтакса сложене реченице у савреме- 
ном српском језику, Београд - Нови Сад: Институт за српски језик - Матица српска, 433-490.

Мразовић 2009: Pavica Mrazović, Gramatika srpskog jezika za strance, Novi Sad -Sremski Karlovci: Izdavačka knjižarnica Zorana Stojanovića.

Свитсер 1990: Eve Sweetser, From Etymology to Pragmatics, Cambridge: CUP. Стевановић 1969: Михаило Стевановић, Савремени српскохрватски језик II, Београд: Научна књига.

Чудомировић 2015a: Јован Чудомировић, Семантика и прагматика саставних одн. супротних напоредних везника и, па, те, а, али, него Београд: Филолошки факултет [необјављена докторска дисертација].

Чудомировић 2015б: Jovan Čudomirović, „Verbs of perception and speech as sources of evidential markers in Serbian: paths of semantic extension and grammatical conventionalization", [in] Björn Wiemer (ed.), Studies on evidentiality marking in West and South Slavic, München: Verlag Otto Sagner, 21-61.

Чудомировић 2016: Јован Чудомировић, „Узрочни субординатори и теорија домена - експериментални приступ", Научни састанак слависта у Вукове дане, 45/3, 167-200.

Чудомировић 2019: Јован Чудомировић, „Условне клаузе и теорија домена”, Научни састанак слависта у Вукове дане, 48/3, 259-278.

Jovan M. Čudomirović

\author{
THE POLYFUNCTIONALITY OF THE CLAUSES WITH THE CONJUNCTION \\ ČIM 'AS SOON AS / SINCE'
}

\title{
Summary
}

The author analyzes the different functions of the clauses with the conjunction čim 'as soon as / since', relying on Sweetser's (1990) notion of different domains of use: the temporal one (content-domain) (Čim je došao, pozvao me je 'As soon as he had come, he called me') and the causal/inferential one (epistemic domain) ( ̌̌im on to kaže, znači da mu se ne dopadaš 'Since he says that, it (surely) means he doesn't like you'). The analysis shows that these uses differ not only semantically, but also in regard to the aspect of the verbs in the subordinate clause and in the matrix clause, and in regard to the position of the čim-clause. It is also showed that the polyfunctionality of these clauses is motivated both by the metonymical closeness between the temporal sequentiality and causality, and by the metaphorical conceptualization of inferential processes as a real-world causality. 